\title{
Different accretion and diagenetic patterns within the fabrics of the Permian-Triassic boundary microbialites on the Leye isolated carbonate platform, South China Block
}

\author{
Xi-Yang Zhang ${ }^{1 *}$ (D) Yue $\mathrm{Li}^{2}$, Guan Wang ${ }^{1}$ and Hong-Qiang Yang ${ }^{1 *}$
}

\begin{abstract}
A comprehensive study on the accretion and diagenesis of the Permian-Triassic boundary microbialites is conducive to a better understanding of the ecological community after the end-Permian mass extinction. Here we studied the special microbialite sequences at the Tianba section of Leye isolated carbonate platform, South China Block. The microbialites are shown as small columnar stromatolites, stromatolitic thrombolites, spotted thrombolites, and domical digitate thrombolites in an ascending order. Thin section analyses, coupled with cathodoluminescence photos and oxygen isotopic data, reveal that all types of microbially-mediated laminae/clots are partly recrystallized. Layers of the Polybessurus-like fossils commonly occur in the recrystallized fabrics of stromatolitic laminae. However, the Polybessurus-like fossils are rare in quantity and generally fragmentary and structureless in stromatolitic clots and spotted clots. Such taphonomic features are likely interpreted as the early decomposition by heterotrophic bacteria in an oxygen-depleted microenvironment caused by rapid accumulations of organic matter in the calm water. More enrichments of ${ }^{13} \mathrm{C}$ in the laminae of stromatolite and in the clots of stromatolitic thrombolite and spotted thrombolite than in adjacent interstitial matrixes signify the photosynthesis-dominated isotopic fractionation during the growth of microbial communities. Rare calcimicrobial structures but many calcite crystal fans were found in the ${ }^{13} \mathrm{C}$-depleted digitate clots. These phenomena indicate that seawater on the carbonate platform was ${ }^{12} \mathrm{C}$-enriched and supersaturated, accelerating carbonate precipitations and decompositions of organic matter within the microbial community. Different preservations of the Polybessurus-like fossil revealed the complicated microbiallydominated sedimentation and post-depositional diagenesis in the abnormal seawater after the catastrophe.
\end{abstract}

Keywords: Microbialite, Calcimicrobe, Carbon isotope, Diagenesis, End-Permian mass extinction, South China Block

\footnotetext{
* Correspondence: zhangxiyang@scsio.ac.cn; hqyang@scsio.ac.cn

'Key Laboratory of Ocean and Marginal Sea Geology, South China Sea

Institute of Oceanology, Innovation Academy of South China Sea Ecology

and Environmental Engineering, Chinese Academy of Sciences, Guangzhou

510301, Guangdong Province, China

Full list of author information is available at the end of the article
}

\section{Springer Open}

(๑) The Author(s). 2021 Open Access This article is licensed under a Creative Commons Attribution 4.0 International License, which permits use, sharing, adaptation, distribution and reproduction in any medium or format, as long as you give appropriate credit to the original author(s) and the source, provide a link to the Creative Commons licence, and indicate if changes were made. The images or other third party material in this article are included in the article's Creative Commons licence, unless indicated otherwise in a credit line to the material. If material is not included in the article's Creative Commons licence and your intended use is not permitted by statutory regulation or exceeds the permitted use, you will need to obtain permission directly from the copyright holder. To view a copy of this licence, visit http://creativecommons.org/licenses/by/4.0/. 


\section{Introduction}

Severe bio-diversity losses during the end-Permian mass extinction (Erwin 2006) promoted the proliferation of benthic microbial communities on the carbonate platforms globally (e.g., Riding 2006; Kershaw et al. 2012; Chatalov 2017). Permian-Triassic boundary microbialites (PTBMs) are mineralized microbial communities with morphological varieties. Some of them underwent extensive diagenesis (Kershaw et al. 1999, 2012; Wu et al. 2018). Calcimicrobial fossils in these microbialites show complex growth patterns in time and space (Ezaki et al. 2008; Kershaw et al. 2012; Adachi et al. 2017; Fang et al. 2017; Wu et al. 2017; Huang et al. 2019; Wang et al. 2019; Zhang et al. 2020). Zhang et al. (2020) noted that the Polybessurus-like fossils (PLFs) with different abundances, arrangements and integrity occurred in microbial structures of stromatolites, thrombolites and dendrites, potentially suggesting a closed relationship between the degree of diagenesis and the environmental parameters. Combining with the abnormal chemical conditions of seawater after the disaster (Baud et al. 2007), further study on causes of the PLFs' preservation discrepancies is necessary.

The PTBMs at the Tianba section of Leye isolated carbonate platform, South China Block (Fig. 1) were employed as representatives of the PLFs occurrences (Zhang et al. 2020). Vertical variations of the PTBM types herein are shown as small domical stromatolites, stromatolitic thrombolites, spotted thrombolites, and domical digitate thrombolites in an ascending order with different microfacies, providing good cases for studying the adaptive strategy of benthic microbial communities and onward diagenetic processes. This study is conducive to gain essential insights of the PTBMs in the aspects of: (i) whether different microbialites viewed on outcrops were essentially related to their original microstructure features; and (ii) how abnormal seawater caused different diagenetic structures in different PTBMs.

\section{Geological setting}

Leye isolated carbonate platform (Feng et al. 1996) was situated in a pull-apart basin of the southwestern South China Block palaeogeographically (Lehrmann et al. 2015; Fig. 1). Uninterrupted Permian-Triassic profiles herein are superior to most hiatus-bearing sections affected by extensive end-Permian regression (Yin et al. 2014). Tianba section $\left(24^{\circ} 49^{\prime} 53^{\prime \prime} \mathrm{N} ; 106^{\circ} 29^{\prime} 35^{\prime \prime} \mathrm{E}\right)$ with continuing shallow marine depositions throughout the Permian-Triassic transition on the intra-platform (Fig. 1)

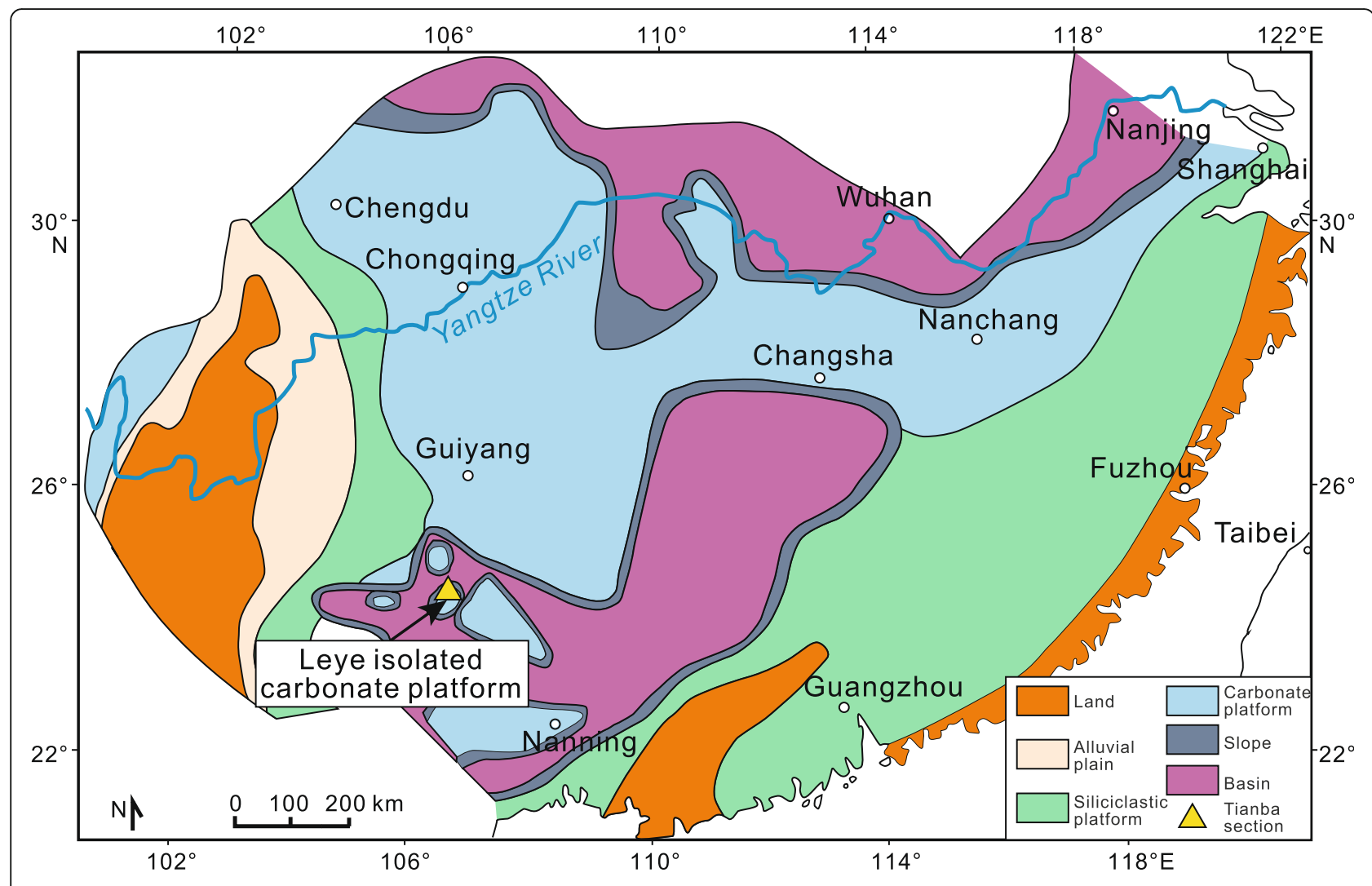

Fig. 1 Location of the Tianba section in Leye isolated carbonate platform within the basin, South China Block (modified after Feng et al. 1996) 
was successively outcropped as bioclastic limestones with ash layers of the upper Changhsingian (Upper Permian) Heshan Formation, microbialites of the basal Luolou Formation throughout the Permian-Triassic transition, and Induan micritic limestone and siliceous rocks (Fig. 2a, b). The microbialite sequence is $3.3 \mathrm{~m}$ in total thickness. The first appearance of Hindeodus parvus, as the index fossil of Permian-Triassic boundary, was recognized at $1.8 \mathrm{~m}$ above the basal microbialite in the previous stratigraphic scheme (Bagherpour et al. 2017) (Fig. 2a). High-resolution U-Pb age-dating from the uppermost ash layer of the Heshan Formation is $252.022 \pm 0.076 \mathrm{Ma}$ (Baresel et al. 2017). The micritic limestone and laminated mudstone overlying the PTBMs at the Tianba section suggest a calm setting.

\section{Methods and material}

We logged the PTBMs with sampling for the lithological and stable isotopic database at the Tianba section. Altogether 11 polished slabs and 195 thin sections were manufactured for microscopic textures and fluorescence observation by using Zeiss Imager.Z2 and Zeiss Axio Zoom.V16 microscope; some of them are tested by cathodoluminescence. 23 ground whole-rock samples were measured for plotting of $\delta^{13} \mathrm{C}_{\text {carb }}$ and $\delta^{18} \mathrm{O}_{\text {carb }}$ curves. Microbially-mediated structures and adjacent interstitial sediments respectively at $0.1 \mathrm{~m}, 0.3 \mathrm{~m}, 0.7 \mathrm{~m}, 1.5 \mathrm{~m}, 2.9$ $\mathrm{m}$, and $3.3 \mathrm{~m}$ above the basal Luolou Formation were sampled by microdrill on the polished slabs, and then tested carbon and oxygen isotopic ratios. 80-100 $\mu \mathrm{g}$ powder of each sample was reacted with orthophosphoric acid for $150-200 \mathrm{~s}$ at $72{ }^{\circ} \mathrm{C}$ in a Kiel IV carbonate device. The released $\mathrm{CO}_{2}$ gas was then tested for ${ }^{13} \mathrm{C}$ and ${ }^{18} \mathrm{O}$ with a MAT-253 mass spectrometer. All isotope values are relative to the VPDB standard. The analytical precision based on duplicate analyses is better than \pm $0.04 \%$ for $\delta^{13} \mathrm{C}$ and $\pm 0.08 \%$ o for $\delta^{18} \mathrm{O}$. All experiments were performed in the State Key Laboratory of Palaeobiology and Stratigraphy of the Nanjing Institute of Geology and Palaeontology, Chinese Academy of Sciences.

\section{Results}

\subsection{Morphology and microfacies of the microbialites}

Four distinct microbialite microfacies at the Tianba section, including small columnar stromatolite, stromatolitic thrombolite, spotted thrombolite, and domical

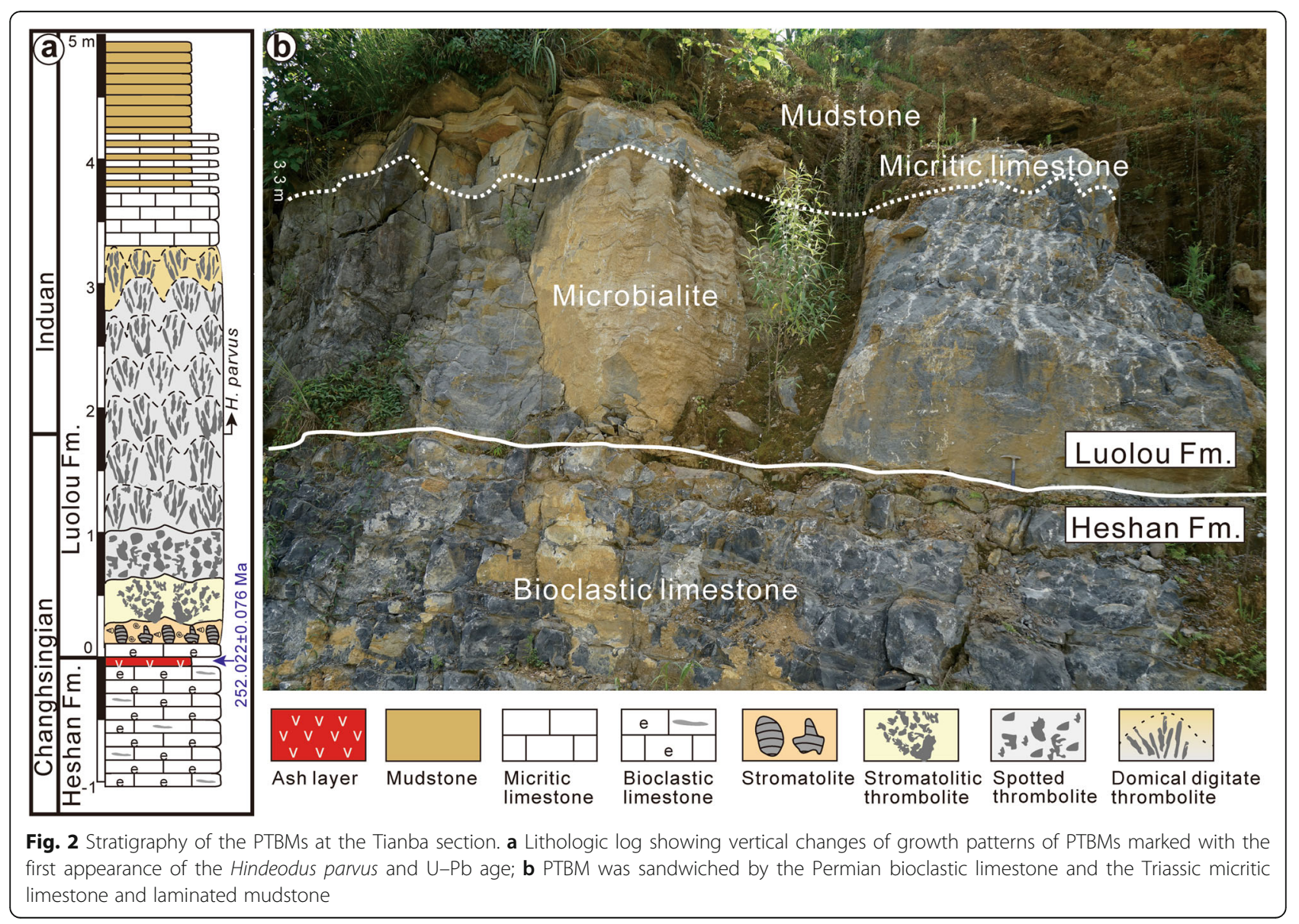


digitate thrombolite in ascending order, are listed in Table 1.

Basal microbialites overlying the bioclastic limestone are mainly composed of columnar stromatolites. Each column is about $4 \mathrm{~cm}$ in height and $2 \mathrm{~cm}$ in width; surrounding interstitial micrites are off-white-yellow in colours and rich in bioclasts of small gastropods, ostracods and foraminifers (Fig. 3a); black-coloured columns comprise alternations of fine-grained laminae and microsparry laminae (Fig. 3b). The fine-grained laminae are composed of layers of the PLFs; each PLF notably shows apical sparry spheres and upright stalks with an almost complete outline and delicate preservation (Fig. 3c). There is no fluorescence within the PLFs (Fig. 3d).

Stromatolitic thrombolites is likely the transitional type between stromatolites and thrombolites morphologically. The boundary between the stromatolitic thrombolite and underlying columnar stromatolites is an uneven surface (Fig. 3a). Above the surface, microbiallymediated laminae are sharply transformed into black pseudo-stratiform clots (Fig. 4a). Patched microsparry calcites (Fig. 4b) with some PLFs are main components of the clots (Fig. 4c). Unlike the stromatolites, the calcimicrobial clusters are commonly discontinuous. Some blurry-shaped PLFs only keep their stacked concave-up laminae (Fig. 4c). Yellow interstitial micrites around the clots are finer-grained than the matrixes in the underlying stromatolites (Fig. 3a).

Stromatolitic thrombolites gradually turn into spotted thrombolites upwards, which of the latter are composed of black clots and off-white interstitial sediments (Fig. 5a). The clots are patched microsparry calcites with interstitial bioclastic and micritic spheroidal limestones
(Fig. 5b). Several irregular chambers similar to the "lobate structures" (named by Kershaw 2017) comprise micritic walls and inner microsparry cavities. Small amounts of poorly-preserved PLFs are visible in the clots (Fig. 5b, c).

The domical digitate thrombolites are the main body of the microbial unit, roughly accounting for a half in thickness (Fig. 2a). The black digitate clots on the slab are in irregular shape with laciniate outer margins, and each clot is about $10 \mathrm{~cm}$ in length and more than $1 \mathrm{~cm}$ in width (Fig. 6a). The digitate clots are branched or gradually merge upwards. The clots comprise microsparry-sparry calcites with their interstitial spaces filled with lime mud and gastropods, ostracods, bivalve, microconchids, and echinoderms fragments (Fig. 6b). Some parallel-arrayed regular digitate clots and brown interstitial sediments are at the topmost microbialite (Fig. 6c). Microsparry and sparry calcites within the clots show discernible vision differences from their adjacent interstitial matrixes (Fig. 6d). Some calcite crystal fans occur within the digitate clot. Each crystal is hexagonal prism shown as elongated rectangular longitudinally (Fig. 6e) and regular hexagonal transversely (Fig. 6f), in line with the crystal shape of aragonite.

\subsection{Cathodoluminescence features of the microbialite}

Cathodoluminescence images illustrate that: (1) more luminescence is in the laminae of stromatolites (Fig. 7a, b) and the thrombolite clots (Fig. 7c-f) than their adjacent interstitial sediments, and (2) red euhedral dolomite grains occur in both the stromatolitic laminae (Fig. 7b) and clots.

Table 1 Microfacies of the Tianba microbialites

\begin{tabular}{|c|c|c|c|c|c|c|}
\hline & \multirow[t]{2}{*}{$\begin{array}{l}\text { Morphological } \\
\text { types }\end{array}$} & \multirow[t]{2}{*}{$\begin{array}{l}\text { Microbially- } \\
\text { mediated structures }\end{array}$} & \multirow[t]{2}{*}{$\begin{array}{l}\text { Interstitial } \\
\text { sediments }\end{array}$} & $\begin{array}{l}\text { PLFs' } \\
\text { abundance }\end{array}$ & PLFs' structure & \multirow[t]{2}{*}{$\begin{array}{l}\text { Calcite } \\
\text { crystal fan }\end{array}$} \\
\hline & & & & High $\rightarrow$ Low & Complete $\rightarrow$ fragmented & \\
\hline 4 & $\begin{array}{l}\text { Domical digitate } \\
\text { thrombolites }\end{array}$ & $\begin{array}{l}\text { Digitate clot } \\
\text { (microsparry- } \\
\text { sparry calcite) }\end{array}$ & $\begin{array}{l}\text { Lime mud } \\
\text { and bioclasts }\end{array}$ & & & Rich \\
\hline 3 & Spotted thrombolite & $\begin{array}{l}\text { Spotted clot } \\
\text { (microsparry- } \\
\text { sparry calcite) }\end{array}$ & $\begin{array}{l}\text { Lime mud } \\
\text { and bioclasts }\end{array}$ & & & Rare \\
\hline 2 & $\begin{array}{l}\text { Stromatolitic } \\
\text { thrombolite }\end{array}$ & $\begin{array}{l}\text { Stromatolitic clot } \\
\text { (microsparry- } \\
\text { sparry calcite) }\end{array}$ & $\begin{array}{l}\text { Lime mud } \\
\text { and bioclasts }\end{array}$ & & & Rare \\
\hline 1 & $\begin{array}{l}\text { Columnar } \\
\text { stromatolite }\end{array}$ & $\begin{array}{l}\text { Laminae } \\
\text { (microsparry- } \\
\text { sparry calcite) }\end{array}$ & $\begin{array}{l}\text { Micritic } \\
\text { calcite and } \\
\text { bioclasts }\end{array}$ & & & Rare \\
\hline
\end{tabular}



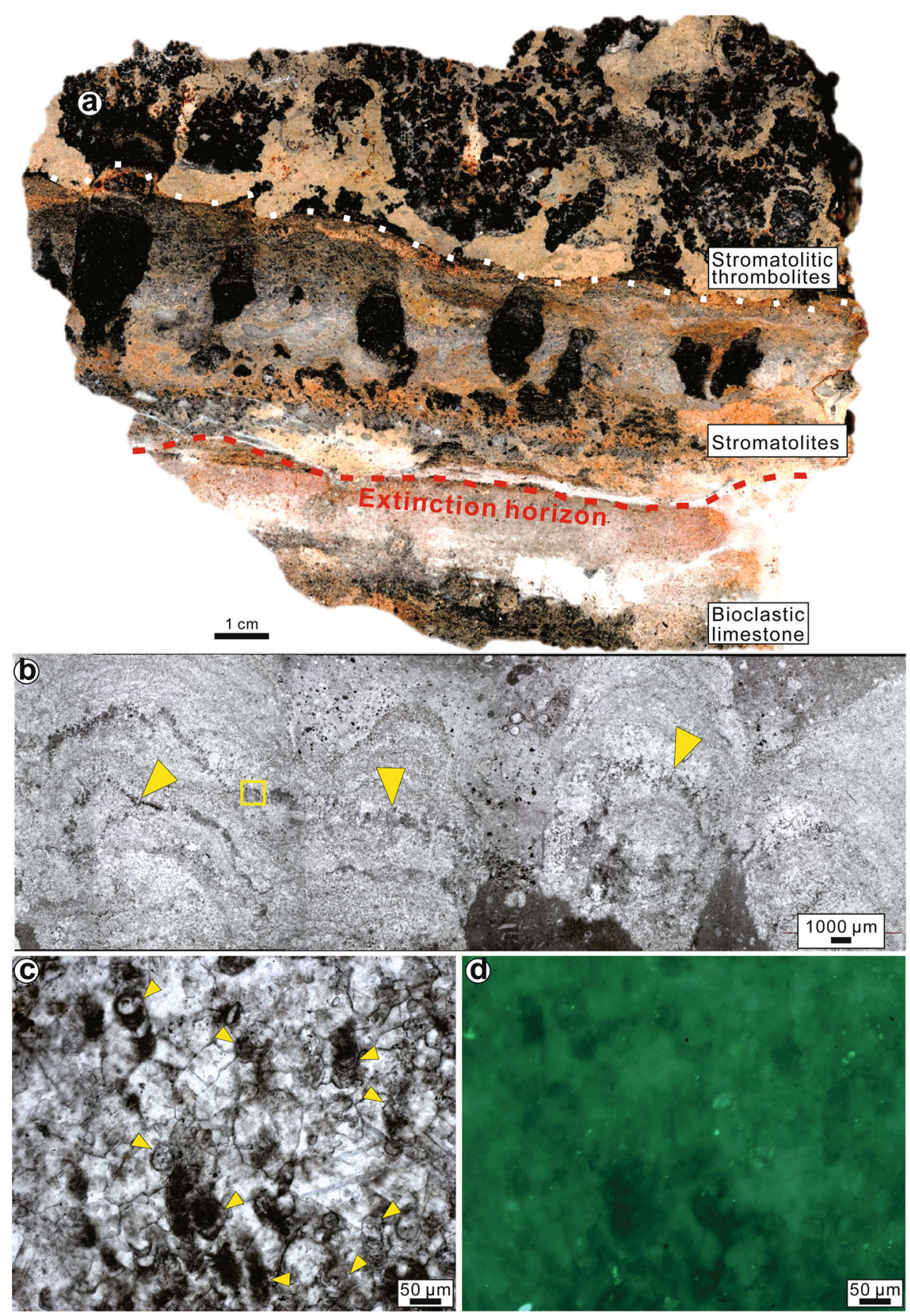

Fig. 3 Mesoscopic and microscopic views of the stromatolites. a Polished slab of the basal microbialite. Small columnar stromatolites grew on the Permian bioclastic limestone separated by maximum extinction horizon (red dashed line). An uneven surface (white dotted line) truncated the stromatolites; b Photomicrograph of stromatolites, showing repeated alterations of fine-grained laminae (marked by arrows) and coarsegrained laminae. Plane-polarized light; $\mathbf{c}$ Enlargement of the rectangle in $\mathbf{b}$, showing well-preserved PLFs (marked by arrows) within the finegrained laminae. Plane-polarized light; $\mathbf{d}$ Bioluminescence of the photo $\mathbf{c}$, showing no luminescence

\subsection{Carbon and oxygen isotope}

In the aspect of chemostratigraphic profile of the whole rock, a broad negative shift of $2.7 \%$ carbon isotope happened at the topmost Heshan Formation (Fig. 8, blue curve). Small $\delta^{13} C_{\text {carb }}$ variations around the extinction horizon do not support a long-term hiatus. Onward depletion of about 1\%o continuously occurred within the microbialites of the basal Luolou Formation, and positive rebounded to $+1 \%$ at the overlying micritic limestone. Oxygen isotope values within this excursion are all between $-5 \%$ and $-8 \%$, signifying that diagenesis has overprinted the study 


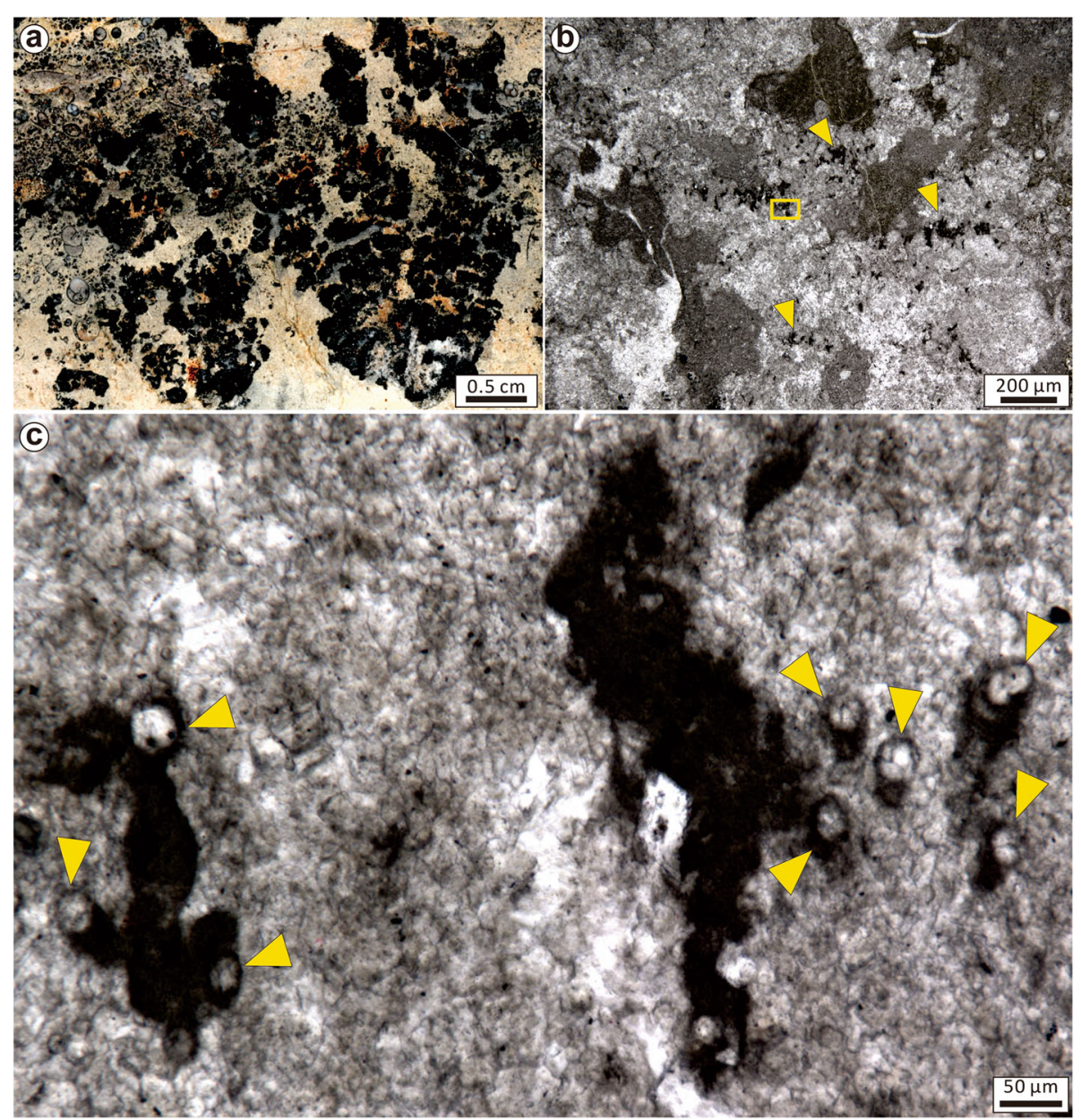

Fig. 4 Mesoscopic and microscopic characteristics of the stromatolitic thrombolites. a Polished slab of the stromatolitic thrombolites; $\mathbf{b}$ Photomicrograph of clots within the stromatolitic thrombolites, showing inhomogeneous microsparry components. PLFs are marked by arrows. Plane-polarized light; $\mathbf{c}$ Enlargement of the rectangle in $\mathbf{b}$, showing structureless and fragmentary PLFs (marked by arrows). Plane-polarized light

interval. No correlation is present between $\delta^{13} \mathrm{C}$ and $\delta^{18} \mathrm{O}$ profiles (Supplementary material).

The same pattern of carbon isotopic profiles respectively from the microbialites (Fig. 8, purple curve) and their interstitial parts (Fig. 8, green curve) proves that microbially-mediated fabrics and interstitial sediments are synsedimentary. The general negative excursion refutes a complete diagenetic overprint in the microbialites. The $\delta^{13} \mathrm{C}_{\text {carb }}$ ratios in laminae of stromatolite, clots of stromatolitic thrombolite and spotted thrombolite are more positive than the adjacent interstitial sediments (Fig. 8). The $\delta^{13} \mathrm{C}_{\text {carb }}$ ratios in the middle part of digitate clots match to their interstitial sediments (Fig. 8). The topmost digitate clots rich in calcite crystal fans show more negative $\delta^{13} \mathrm{C}_{\text {carb }}$ ratio than their matrixes (Fig. 8). Detailed carbon isotope data and analysis of the correlation between carbon and oxygen isotopes are presented in Supplementary material.

\section{Discussion}

Abnormal seawater during the Permian-Triassic transition synthetically controlled the depositional and diagenetic processes of the PTBMs. The lithological and isotopic data of the Tianba section supply evidence on the closed relationship between fabrics formation of the PTBMs and environmental parameters especially turbulent condition of the seawater.

\subsection{Depositional process of the PTBMs}

Development of PTBMs started in line with the earliest Triassic transgression (Bagherpour et al. 2017; Huang et al. 2019; Wang et al. 2019) and temporarily ceased following the sea-level rise in Nanpanjiang Basin (Bagherpour et al. 2017). Foster et al. (2020) regarded that stromatolites and thrombolites should grow on turbulent and well-oxygenated marine-floor near storm 

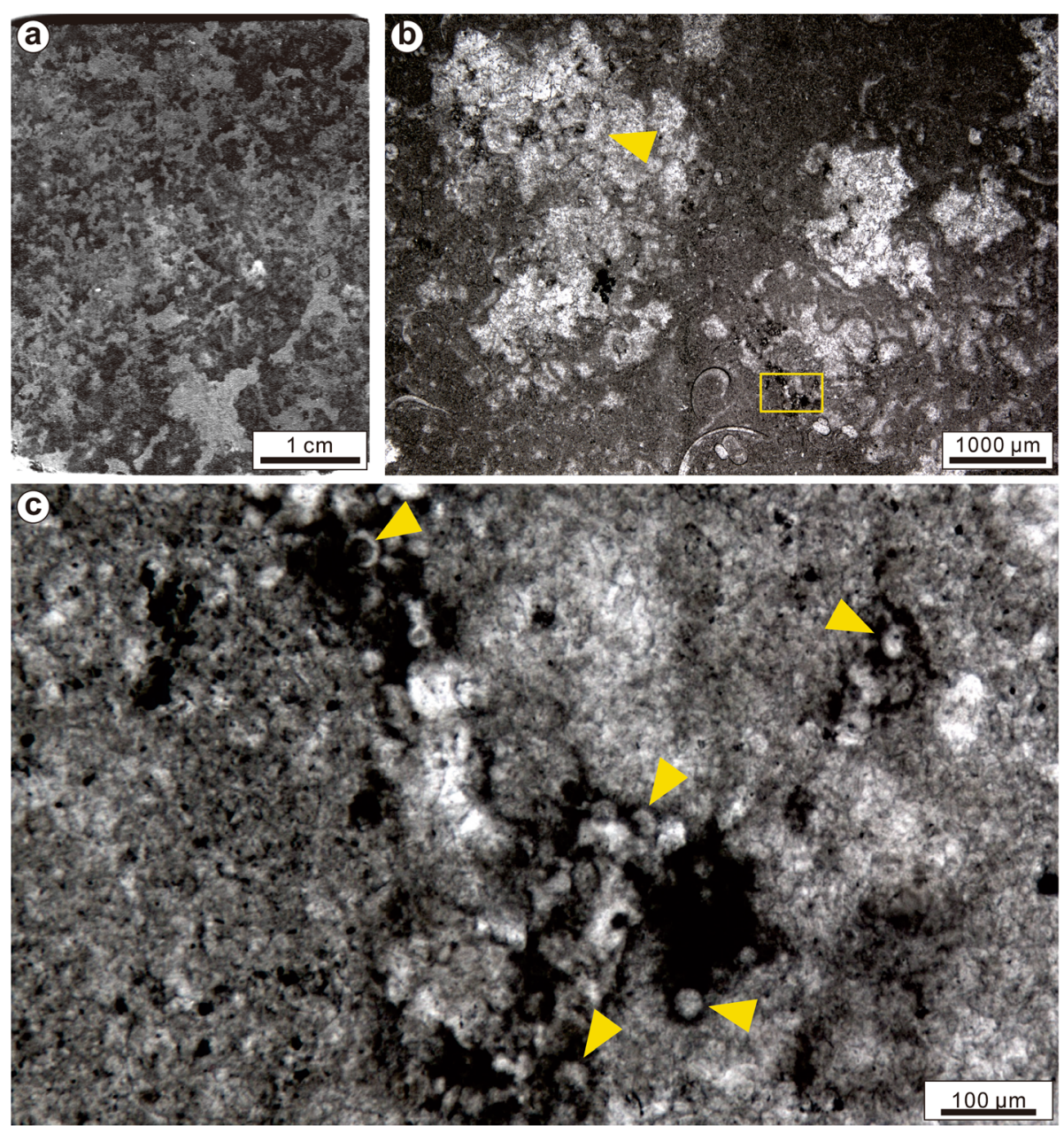

Fig. 5 Mesoscopic and microscopic characteristics of the spotted thrombolites. a Polished slab of the spotted thrombolites, showing black clots and grey interstitial sediments; $\mathbf{b}$ Photomicrograph of microsparry spotted clots and micritic interstitial sediments. "Lobate structures" are marked by the arrow. Plane-polarized light; $\mathbf{c}$ Enlargement of the rectangle in $\mathbf{b}$, showing poorly-preserved PLFs (marked by arrows). Plane-polarized light

wave-base, where allochthonous sediments and bioclasts are frequently and richly transported by storm-induced currents. Therefore, the grain sizes of the interstitial sediments could be considered as key hydrodynamic parameters. The coarse-grained interstitial sediments near the columnar stromatolites deposited in more turbulent condition, while fine-grained clasts between the thrombolites clots were likely transported by lower-energy currents.

In consistency with hydrodynamic changes, the PLFs in the benthic microbial communities change their growth strategies. In situ preserved PLFs in stromatolites are more tightly in growth style as mat-like laminae efficiently preventing being washed away. However, in a weak turbulent marine-floor, the PLFs favourably maintained their longitudinal growth as algal clumps and finally into clots. The stromatolitic thrombolite (Figs. 3 and $4 \mathrm{a}$ ), as the important transitional type, well illustrates the continuous morphological changes of the benthic microbial communities from two-dimension mats to three-dimension bulges.

\subsection{Early diagenesis of the PTBMs}

Modern stromatolites precipitate unstable aragonitic nanogranules within mucilage sheaths (Kremer et al. 2012). The following crystals growth and mineralogical changes from aragonitic nanogranules into chemicallystable calcites and/or dolomites (Chagas et al. 2016) will result in the decrease of organic matter content and reformation of the original fabrics. Cathodoluminescence images (Fig. $7 \mathrm{a}-\mathrm{f}$ ) and the oxygen isotopic ratios reveal all kinds of microbialites at the Tianba section have 

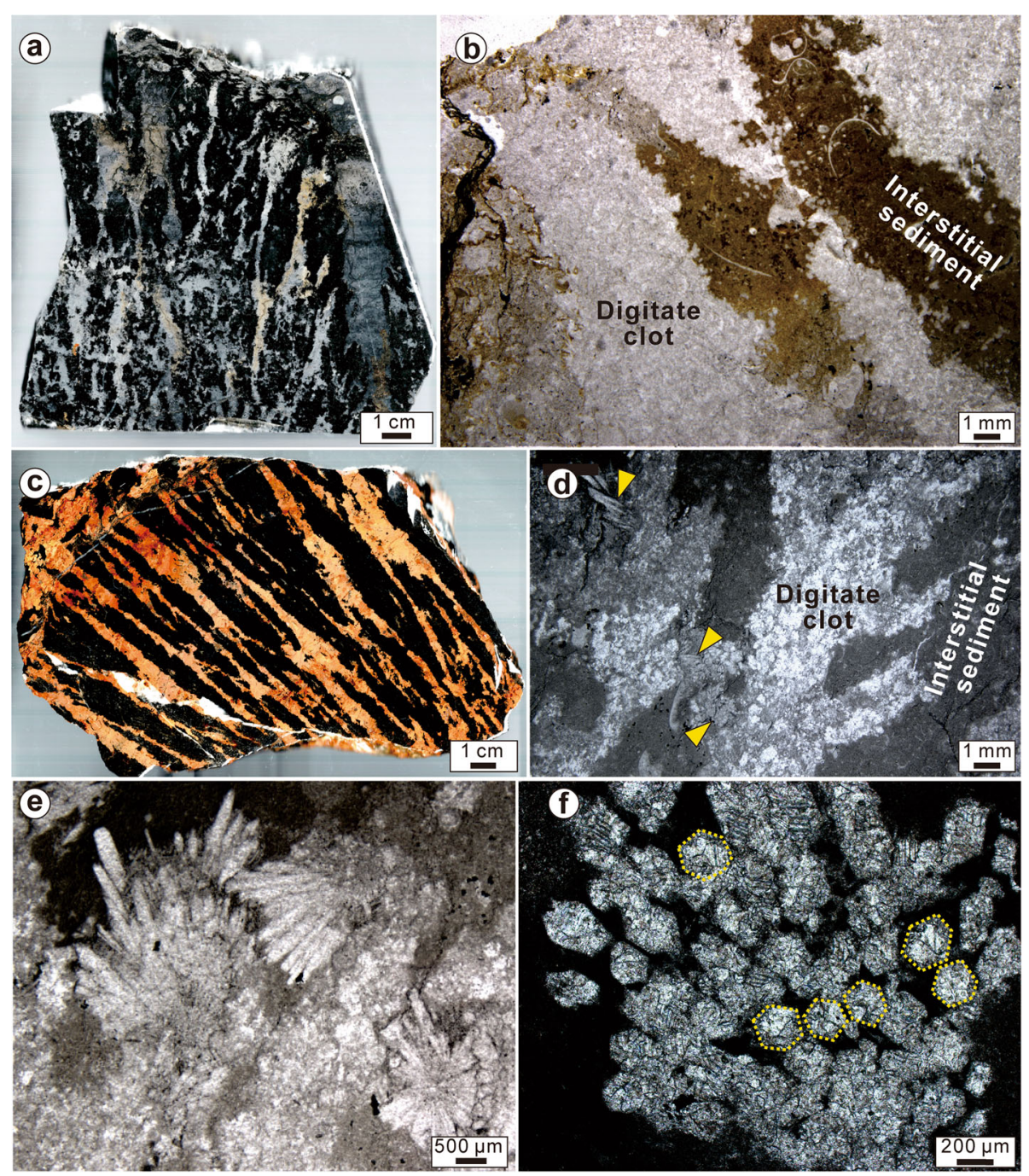

Fig. 6 Mesoscopic and microscopic characteristics of the digitate thrombolites. a Polished slab of the middle part of domical digitate thrombolites; b Photomicrograph of the digitate clot, showing microsparry-sparry components and micritic interstitial parts. Plane-polarized light; c Polished slab of the uppermost digitate thrombolites; d Photomicrograph of the uppermost digitate clot, showing microsparry-sparry components and micritic interstitial parts. Some calcite crystal fans are marked by arrows. Plane-polarized light; e Hemispheric crystal fan comprising many elongate crystals. Plane-polarized light; f Transverse section showing regular hexagonal crystals. Plane-polarized light

overprinted by diagenesis and neomorphism. Nevertheless, the slight difference between microbially-mediated structures and their background sediments are recognised by carbon isotope. PLFs, as coccoid cyanobacteria (Zhang et al. 2020) induce the carbonate precipitation with a remarkable enrichment of ${ }^{13} \mathrm{C}$ (O'Leary 1988). The stromatolite laminae with more positive $\delta^{13} \mathrm{C}_{\text {carb }}$ ratios reflect the photosynthesis-mediated calcification. The microbial mats dominated by autotroph microorganisms are of the greatest biosignature preservation generally (Fig. 9). Cyanobacteria precipitate the carbonate grains by providing supersaturated alkaline microenvironments and crystallization templates-extracellular polymeric substances (Arp et al. 2001; Dupraz et al. 2009). Meanwhile, the agitated and oxidizing sea-floor prohibited the proliferation of anaerobic bacteria and the degradation of cyanobacterial extracellular polymeric substances, which prolonged calcification and enhanced microbial fossilization.

Carbon isotope values (Fig. 8) suggested that both stromatolitic clots and spotted clots were photosynthesisdominated calcification, but the fragmentary PLFs implied they were not well lithified (Fig. 9). The attenuated agitation in currents and rapid accumulation of organic matter might rapidly cause oxygen depletion below the surficial sediments and favour anaerobic bacteria thriving. 

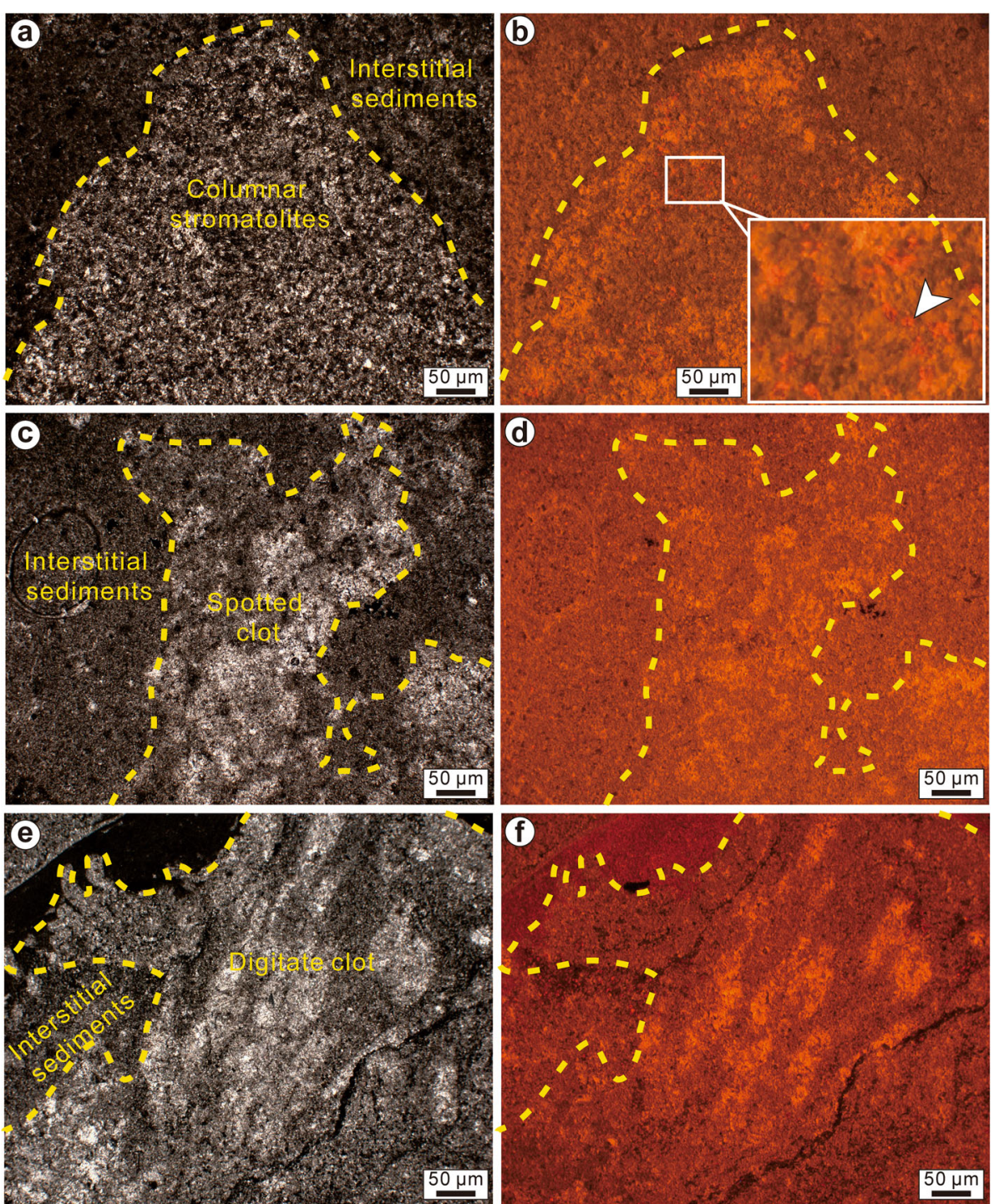

Fig. 7 Cathodoluminescence photos of different microbialite pattern. a Photomicrograph of the columnar stromatolites and interstitial sediments Plane-polarized light; $\mathbf{b}$ Cathodoluminescence of the photo $\mathbf{a}$, showing more luminescence in stromatolites than in interstitial sediments. Red crystals marked by the arrow are dolomites; c Photomicrograph of spotted clots and interstitial sediments. Plane-polarized light; d Cathodoluminescence of the photo $\mathbf{c}$, showing more luminescence in spotted clots than in interstitial micrites; e Photomicrograph of digitate clots and interstitial sediments. Plane-polarized light; $\mathbf{f}$ Cathodoluminescence of photo $\mathbf{e}$, showing more luminescence in digitate clots than in surroundings

Decompositions of organics, especially extracellular polymeric substance by anaerobic bacteria broke the crystal template and caused the poor-preservations of the PLFs.

The approximately equal $\delta^{13} C_{\text {carb }}$ ratios in digitate clots and matrixes (Fig. 8) seemingly demonstrate that the microbialites grew in equilibrium with seawater. Similar carbon isotopic results were displayed in the Permian-Triassic digitate thrombolites at the Laolongdong section of Chongqing ( $\mathrm{Mu}$ et al. 2009). Zhang et al. (2020) reported that the digitate clots at the Yudongzi section of Sichuan comprised both PLFs-bearing laminae and calcite carbonate fans. However, rare calcimicrobial fossils at the Tianba section were probably due to the early diagenesis which reduced the photosynthesisrelated ${ }^{13} \mathrm{C}$. The ${ }^{13} \mathrm{C}$ depletion in the calcite crystal fans at the topmost digitate thrombolites implied ${ }^{12} \mathrm{C}$ enriched seawater dominated the shallow carbonate platform. This scenario might be closely related to the special oceanographical pattern with extensive Early Triassic upwellings (e.g., Knoll et al. 1996; Woods et al. 


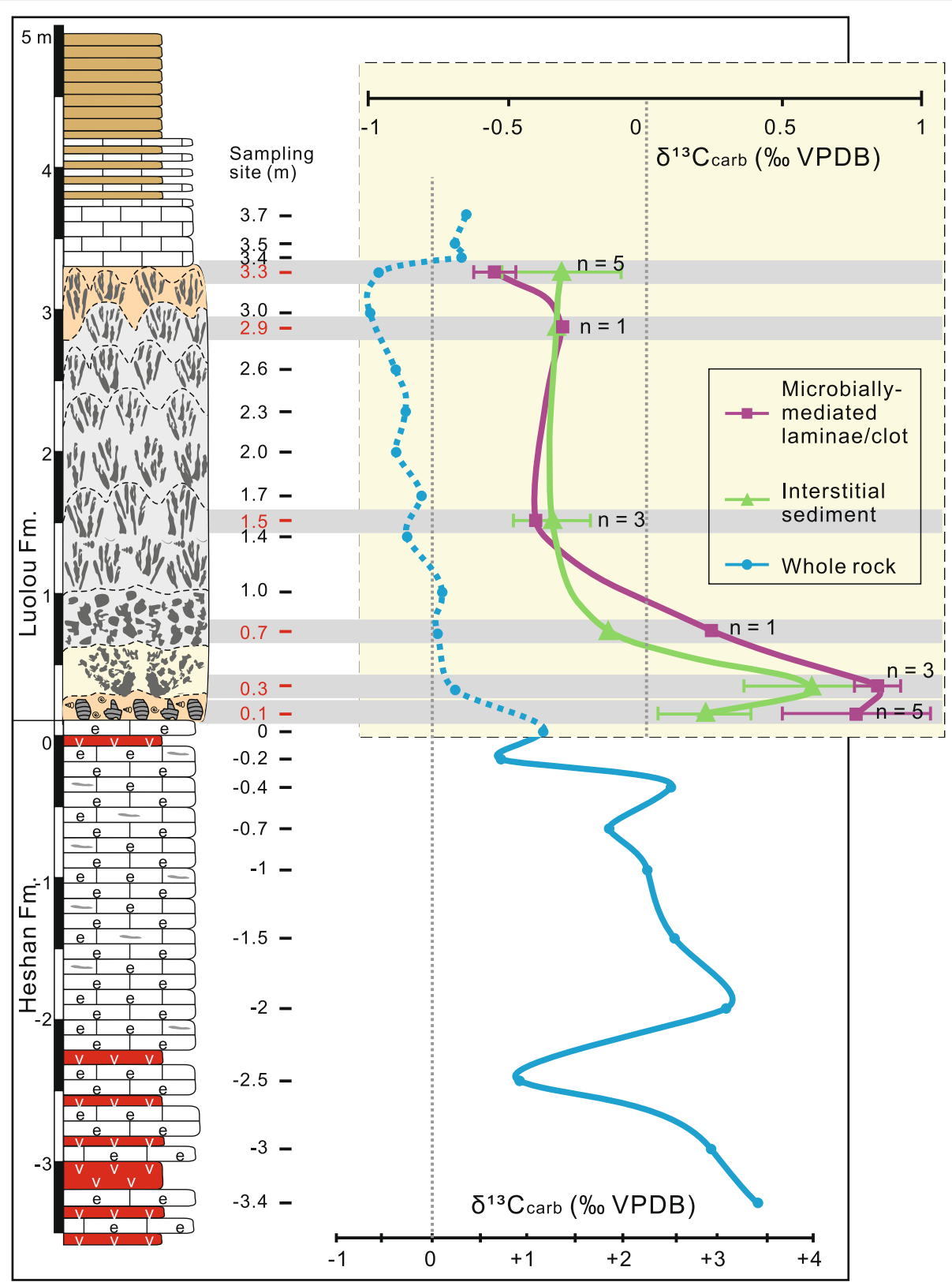

Fig. 8 Carbon isotopic curve of the whole rock (blue line; referring to the bottom scale), and carbon isotopic curves of microbially-mediated structures (purple line; referring to the upper scale) and interstitial sediments (green line; referring to the upper scale) from the $0.1 \mathrm{~m}, 0.3 \mathrm{~m}, 0.7 \mathrm{~m}$, 1.5 m, 2.9 m, $3.3 \mathrm{~m}$ (marked red). $n$ = number of samples. Lithological legends refer to Fig. 2

1999; Heydari and Hassanzadeh 2003; Pruss and Bottjer 2004; Woods 2014; Friesenbichler et al. 2018). The anoxic deep-water upwelled to shallow carbonate platforms and brought adequate alkalinity, and supersaturated seawaters promoted carbonate precipitations in the Tethyan (Kershaw 2017). The rapid crystallization within the microbial frameworks protruded the sub-parallel digitate clots from the substrate, and the open channels allowed sufficient exchanges between the microbialites and the abnormal seawater. The overgrowth of crystals (from nanoparticles to coarse grains) and potential heterotrophic decomposition then destroyed organic texture including the bodies of the PLFs, causing the least biosignature preservation.

\section{Conclusions}

Microfacies and carbon isotope database of the PTBMs at the Tianba section of Leye isolated carbonate platform provide a better understanding of their growth patterns 


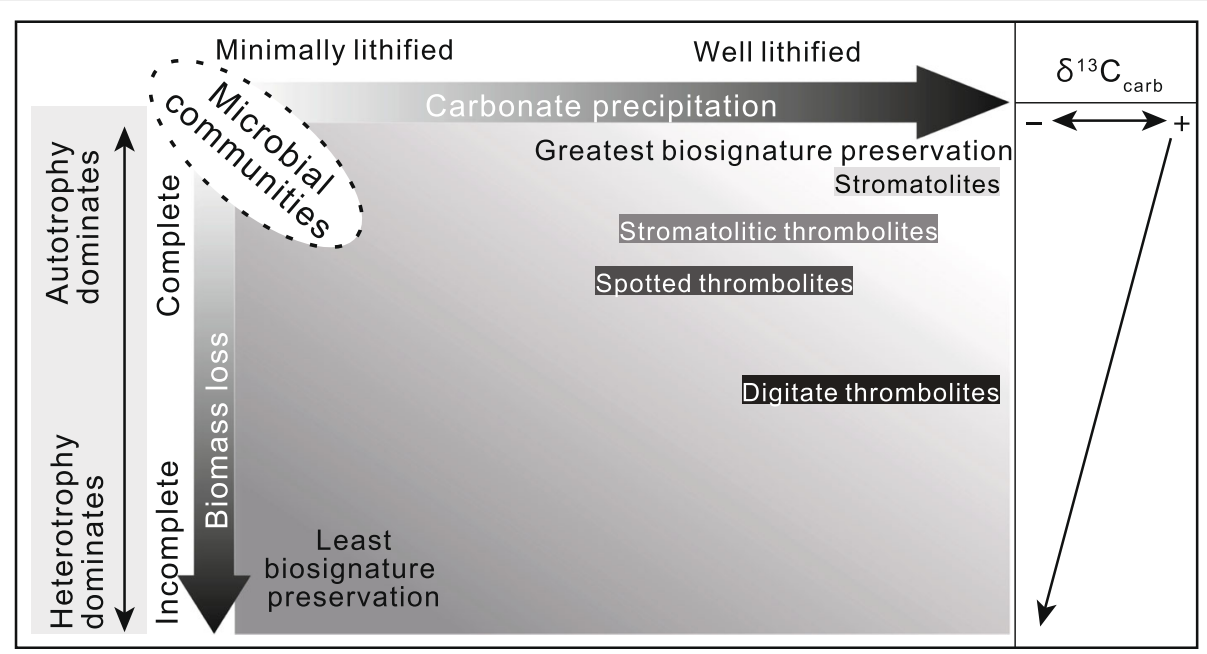

Fig. 9 Preservation of PLFs and the carbon isotopic trends of different types of PTBMs at Tianba section (modified after Harwood 2013). Autotrophy microbes are well lithified in stromatolites, but are less well lithified in stromatolitic thrombolites and spotted thrombolites due to the decomposition of heterotrophic bacteria. Anoxic and supersaturated seawater dramatically reduce biomass resulting in biosignature loss in digitate thrombolites. The $\delta^{13} C_{\text {carb }}$ values gradually turn negative with the intensified activities of heterotrophic bacteria

and diagenetic processes. The sea-level and hydrodynamic changes are the most significant factors in the formation of biotic structures of microbial communities. PLFs in stromatolites are well lithified with the greatest biosignature preservation. Abnormal seawater caused uneven diagenesis especially impacts in the fabrics of PLFs simultaneously according to the changeable environmental parameters; their poor-preservations in stromatolitic clots and spotted clots indicate the early microbial decomposition. Massive occurrences of calcite crystal fan in digitate clots reinforced that the supersaturated seawater upwelled onto the carbonate platform and promoted the rapid carbonate precipitation and decomposition of organic matter.

\section{Abbreviations}

PTBMs: Permian-Triassic boundary microbialites; PLFs: Polybessurus-like fossils

\section{Supplementary Information}

The online version contains supplementary material available at https://doi. org/10.1186/s42501-021-00091-3.

Additional file 1 Supplementary material: Carbon and oxygen isotopic ratios at this study.

\section{Acknowledgements}

The authors sincerely thank Dr. Quan-Feng Zheng from Nanjing Institute of Geology and Palaeontology for his assistances in the fieldwork. We are grateful for the constructive comments provided by the reviewers.

\section{Authors' contributions}

$X Y Z$ measured the studied section and collected the samples. The figures were prepared by $X Y Z$. XYZ and YL drafted the manuscript, and $X Y Z$ did the final version of the manuscript that was then read and approved by GW and HQY. All authors approved the final manuscript.

\section{Funding}

This work was financially supported by the Strategic Priority Research Program of the Chinese Academy of Sciences (No. XDA13010103), the National Natural Science Foundation of China (No. 41506061), and Special Fund for Strategic Pilot Technology of Chinese Academy of Sciences (type B, No. XDB26000000).

\section{Availability of data and materials}

All data generated or analysed during this study are included in this published article and its supplementary information file.

\section{Declarations}

\section{Competing interests}

The authors declare that they have no competing interests. All authors have approved this manuscript and no author has financial or other contractual agreements that might cause conflicts of interest.

\section{Author details}

${ }^{1}$ Key Laboratory of Ocean and Marginal Sea Geology, South China Sea Institute of Oceanology, Innovation Academy of South China Sea Ecology and Environmental Engineering, Chinese Academy of Sciences, Guangzhou 510301, Guangdong Province, China. ${ }^{2}$ State Key Laboratory of Palaeobiology and Stratigraphy, Nanjing Institute of Geology and Palaeontology and Center for Excellence in Life and Paleoenvironment, Chinese Academy of Sciences, Nanjing 210008, Jiangsu Province, China.

Received: 29 July 2020 Accepted: 16 April 2021

Published online: 12 May 2021

\section{References}

Adachi, N., Y. Asada, Y. Ezaki, and J.B. Liu. 2017. Stromatolites near the Permian-Triassic boundary in Chongyang, Hubei Province, South China: A geobiological window into palaeo-oceanic fluctuations following the end-Permian extinction. Palaeogeography, Palaeoclimatology, Palaeoecology 475: 55-69. https://doi.org/10.1016/j.palaeo.2017.01.030.

Arp, G., A. Reimer, and J. Reitner. 2001. Photosynthesis-induced biofilm calcification and calcium concentrations in Phanerozoic oceans. Science 292 (5522): 1701-1704. https://doi.org/10.1126/science.1057204.

Bagherpour, B., H. Bucher, A. Baud, M. Brosse, T. Vennemann, R. Martini, and K. Guodun. 2017. Onset, development, and cessation of basal Early Triassic microbialites (BETM) in the Nanpanjiang pull-apart basin, South 
China Block. Gondwana Research 44: 178-204. https://doi.org/10.1016/j. gr.2016.11.013.

Baresel, B., H. Bucher, B. Bagherpour, M. Brosse, G.D. Kuang, and U. Schaltegger. 2017. Timing of global regression and microbial bloom linked with the Permian-Triassic boundary mass extinction: Implications for driving mechanisms. Scientific Reports 7 (1): 43630. https://doi.org/1 $0.1038 /$ srep43630.

Baud, A., S. Richoz, and S. Pruss. 2007. The lower Triassic anachronistic carbonate facies in space and time. Global and Planetary Change 55 (13): 81-89. https://doi.org/10.1016/j.gloplacha.2006.06.008.

Chagas, A.A.P., G.E. Webb, R.V. Burne, and G. Southam. 2016. Modern lacustrine microbialites: Towards a synthesis of aqueous and carbonate geochemistry and mineralogy. Earth-Science Reviews 162: 338-363. https://doi.org/10.1016/j.earscirev.2016.09.012.

Chatalov, A. 2017. Anachronistic and unusual carbonate facies in uppermost lower Triassic rocks of the western Balkanides, Bulgaria. Facies 63 (4): 24 https://doi.org/https://doi.org/10.1007/s10347-017-0505-0.

Dupraz, C., R.P. Reid, O. Braissant, A.W. Decho, R.S. Norman, and P.T. Visscher. 2009. Processes of carbonate precipitation in modern microbial mats. Earth-Science Reviews 96 (3): 141-162. https://doi.org/10.1016/j.ea rscirev.2008.10.005.

Erwin, D.H. 2006. Extinction: How life on earth nearly ended 250 million years ago. Princeton: Princeton University Press.

Ezaki, Y., J.B. Liu, T. Nagano, and N. Adachi. 2008. Geobiological aspects of the earliest Triassic microbialites along the southern periphery of the tropical Yangtze platform: Initiation and cessation of a microbial regime. Palaios 23 (6): 356-369. https://doi.org/10.2110/palo.2007.p07-035r.

Fang, Y.H., Z.Q. Chen, S. Kershaw, H. Yang, and M. Luo. 2017. PermianTriassic boundary microbialites at Zuodeng section, Guangxi Province, South China: Geobiology and palaeoceanographic implications. Global and Planetary Change 152: 115-128. https://doi.org/10.1016/j.gloplacha.2 017.02.011.

Feng, Z.Z., Y.Q. Yang, Z.K. Jin, Y.B. He, S.H. Wu, W.J. Xin, Z.D. Bao, and J. Tan. 1996. Lithofacies paleogeography of the Permian of South China. Acta Sedimentologica Sinica 14 (2): 1-11 (in Chinese with English abstract).

Foster, W.J., K. Heindel, S. Richoz, J. Gliwa, D.J. Lehrmann, A. Baud, T. KolarJurkovšek, D. Aljinović, B. Jurkovšek, D. Korn, R.C. Martindale, and J. Peckmann. 2020. Suppressed competitive exclusion enabled the proliferation of Permian/Triassic boundary microbialites. The Depositional Record 6 (1): 62-74. https://doi.org/10.1002/dep2.97.

Friesenbichler, E., S. Richoz, A. Baud, L. Krystyn, L. Sahakyan, S. Vardanyan, J. Peckmann, J. Reitner, and K. Heindel. 2018. Sponge-microbial build-ups from the lowermost Triassic Chanakhchi section in southern Armenia: Microfacies and stable carbon isotopes. Palaeogeography, Palaeoclimatology, Palaeoecology 490: 653-672. https://doi.org/10.1016/j.palaeo.2017.11.056.

Harwood, C.L. 2013. Microbial and Metazoan Influences on Microbialite Growth Structures: Insights from Recent Lacustrine Microbialites in Pavilion Lake, BC, and Cambrian Thrombolites from the Great Basin, CA and NV [Ph.D. Thesis], 339. Davis: University of California.

Heydari, E., and J. Hassanzadeh. 2003. Deev Jahi model of the PermianTriassic boundary mass extinction: A case for gas hydrates as the main cause of biological crisis on earth. Sedimentary Geology 163 (1-2): 147163. https://doi.org/10.1016/j.sedgeo.2003.08.002.

Huang, Y.F., D.P.G. Bond, Wang, Y.B, T. Wang, Yi, Z.X, A.H. Yuan, Jia, J.Y, and Y.Q. Su. 2019. Early Triassic microbialites from the Changxing region of Zhejiang Province, South China. Journal of Palaeogeography 8 (3): 225237. https://doi.org/https://doi.org/10.1186/s42501-019-0039-1.

Kershaw, S. 2017. Palaeogeographic variation in the Permian-Triassic boundary microbialites: A discussion of microbial and ocean processes after the end-Permian mass extinction. Journal of Palaeogeography 6 (2): 97-107. https://doi.org/10.1016/j.jop.2016.12.002.

Kershaw, S., S. Crasquin, Y. Li, P.Y. Collin, M.B. Forel, X.N. Mu, A. Baud, Y. Wang, S. Xie, F. Maurer, and L. Guo. 2012. Microbialites and global environmental change across the Permian-Triassic boundary: A synthesis. Geobiology 10 (1): 25-47. https://doi.org/10.1111/j.1472-4669.2011.00302.x.

Kershaw, S., T.S. Zhang, and G.Z. Lan. 1999. A ?Microbialite carbonate crust at the Permian-Triassic boundary in South China, and its palaeoenvironmental significance. Palaeogeography, Palaeoclimatology, Palaeoecology 146 (1-4): 1-18. https://doi.org/10.1016/S0031-0182 (98)00139-4.

Knoll, A.H., R.K. Bambach, D.E. Canfield, and J.P. Grotzinger. 1996 Comparative earth history and late Permian mass extinction. Science 273 (5274): 452-457. https://doi.org/10.1126/science.273.5274.452.

Kremer, B., J. Kazmierczak, M. Łukomska-Kowalczyk, and S. Kempe. 2012 Calcification and silicification: Fossilization potential of cyanobacteria from stromatolites of Niuafo'ou's Caldera Lakes (Tonga) and implications for the early fossil record. Astrobiology 12 (6): 535-548. https://doi.org/1 0.1089/ast.2011.0742.

Lehrmann, D.J., J.M. Bentz, T. Wood, A. Goers, R. Dhillon, S. Akin, X. Li, J.L. Payne, B.M. Kelley, K.M. Meyer, E.K. Schaal, M.B. Suarez, M. Yu, Y. Qin, R. Li, M. Minzoni, and C.M. Henderson. 2015. Environmental controls on the genesis of marine microbialites and dissolution surface associated with the end-Permian mass extinction: New sections and observations from the Nanpanjiang Basin, South China. Palaios 30 (7): 529-552. https://doi.org/10.2110/palo.2014.088.

Mu, X.N., S. Kershaw, Y. Li, L. Guo, Y.P. Qi, and A. Reynolds. 2009. Highresolution carbon isotope changes in the Permian-Triassic boundary interval, Chongqing, South China; implications for control and growth of earliest Triassic microbialites. Journal of Asian Earth Sciences 36 (6): 434-441. https://doi.org/10.1016/j.jseaes.2007.08.004.

O'Leary, M.H. 1988. Carbon isotopes in photosynthesis: Fractionation techniques may reveal new aspects of carbon dynamics in plants. BioScience 38 (5): 328-336. https://doi.org/10.2307/1310735.

Pruss, S.B., and D.J. Bottjer. 2004. Early Triassic trace fossils of the western United States and their implications for prolonged environmental stress from the end-Permian mass extinction. Palaios 19 (6): 551-564. https:// doi.org/10.1669/0883-1351(2004)019<0551:ETTFOT>2.0.CO;2.

Riding, R. 2006. Microbial carbonate abundance compared with fluctuations in metazoan diversity over geological time. Sedimentary Geology 185 (34): 229-238. https://doi.org/10.1016/j.sedgeo.2005.12.015.

Wang, T., R.V. Burne, A.H. Yuan, Y.B. Wang, and Z.X. Yi. 2019. The evolution of microbialite forms during the Early Triassic transgression: A case study in Chongyang of Hubei Province, South China. Palaeogeography, Palaeoclimatology, Palaeoecology 519: 209-220. https://doi.org/10.1016/j. palaeo.2018.01.043.

Woods, A.D. 2014. Assessing Early Triassic paleoceanographic conditions via unusual sedimentary fabrics and features. Earth-Science Reviews 137: 618. https://doi.org/10.1016/j.earscirev.2013.08.015.

Woods, A.D., D.J. Bottjer, M. Mutti, and J. Morrison. 1999. Lower Triassic large sea-floor carbonate cements: Their origin and a mechanism for the prolonged biotic recovery from the end-Permian mass extinction. Geology 27 (7): 645-648. https://doi.org/10.1130/0091-7613(1999)027< 0645:LTLSFC $>2.3 . C 0 ; 2$

Wu, S.Q., Z.Q. Chen, Y.H. Fang, Y. Pei, H. Yang, and J. Ogg. 2017. A PermianTriassic boundary microbialite deposit from the eastern Yangtze platform (Jiangxi Province, South China): Geobiologic features, ecosystem composition and redox conditions. Palaeogeography, Palaeoclimatology, Palaeoecology 486: 58-73. https://doi.org/10.1016/j.palaeo.2017.05.015.

Wu, Y.S., H.X. Jiang, G.L. Yu, and L.J. Liu. 2018. Conceptions of microbialites and origin of the Permian-Triassic boundary microbialites from Laolongdong, Chongqing, China. Journal of Palaeogeography (Chinese Edition) 20 (5): 737-775 (in Chinese with English abstract).

Yin, H.F., H.S. Jiang, Xia, W.C, Q.L. Feng, Zhang, N, and J. Shen. 2014. The end-Permian regression in South China and its implication on mass extinction. Earth-Science Reviews 137 (supplement C): 19-33.

Zhang, X.Y., Q.F. Zheng, Li, Y, H.Q. Yang, Zhang, H, W.Q. Wang, and Shen, S. Z. 2020. Polybessurus-like fossils as key contributors to Permian-Triassic boundary microbialites in South China. Palaeogeography, Palaeoclimatology, Palaeoecology 552: 109770. https://doi.org/https:// doi.org/10.1016/j.palaeo.2020.109770.

\section{Publisher's Note}

Springer Nature remains neutral with regard to jurisdictional claims in published maps and institutional affiliations. 